Winter 2011

\title{
Ethnographies of Indigenous Exclusion in Western Mexico
}

Guillermo de la Peña

Centro de Investigaciones y Estudios Superiores en Antropologia Social (CIESAS)-Guadalajara, Mexico.

Follow this and additional works at: https://www.repository.law.indiana.edu/ijgls

Part of the International Law Commons

\section{Recommended Citation}

de la Peña, Guillermo (2011) "Ethnographies of Indigenous Exclusion in Western Mexico," Indiana Journal of Global Legal Studies: Vol. 18 : Iss. 1 , Article 13.

Available at: https://www.repository.law.indiana.edu/ijgls/vol18/iss1/13

This Symposium is brought to you for free and open access by the Law School Journals at Digital Repository @ Maurer Law. It has been accepted for inclusion in Indiana Journal of Global Legal Studies by an authorized editor of Digital Repository @ Maurer Law. For more information, please contact rvaughan@indiana.edu.

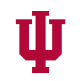

JEROME HALL LAW LIBRARY

$$
\text { INDIANA UNIVERSITY }
$$

Maurer School of Law
Blooming ton 


\title{
Ethnographies of Indigenous Exclusion in Western Mexico
}

\author{
GUILLERMO DE LA PEÑA*
}

\begin{abstract}
In 1992 and 2001, the National Congress of Mexico approved several amendments to the constitution concerning the legal status and rights of indigenous peoples. However, the specific institutional aspects and practical implications of these changes were left to state legislatures, which have responded slowly and unevenly. A particular problem has been the lack of a clear definition of what indigenous political representation means for the different levels of the Mexican government. This article uses ethnographic materials collected in the state of Jalisco to document certain forms of exclusion and violations of citizen rights that relate to voids and ambiguities in legislation. It also contends that efficient representation necessitates an intercultural dialogue that accepts differences without essentializing them.

During the last twenty years, a number of important changes concerning the legal status of the indigenous population have occurred in Mexico. In 1991, the Mexican government signed the International Labour Organization's Indigenous and Tribal Peoples Convention, which expanded the rights of indigenous and tribal peoples; ${ }^{1}$ consequently, at the end of the same year, the National Congress approved a change in Article 4 of the constitution. In its new version, this article declared that Mexico was a multicultural and pluriethnic

* Professor of Anthropology, Centro de Investigaciones y Estudios Superiores en Antropología Social (CIESAS)-Guadalajara, Mexico. D.Phil, 1977, University of Manchester; M.A., 1970, University of Manchester; B.A., 1967, Instituto Libre de Filosofia y Ciencias-Mexico City.

1. Also known as the Convention 169 , the document was met with approval at the 76th reunion of the General Conference of the International Labour Organization, which convened in Geneva, Switzerland, on June 7, 1989. Int'l Labour Org. [ILO], Convention (No. 169) Concerning Indigenous and Tribal Peoples in Independent Countries, adopted June 27, 1989, 1650 U.N.T.S. 383, available at http://www.ilo.org/ilolex/cgi-lex/convde. pl?C169.
\end{abstract}

Indiana Journal of Global Legal Studies Vol. 18 \#1 (Winter 2011)

(C) Indiana University Maurer School of Law 
nation, "based originally upon its indigenous peoples."2 For the first time in Mexican history, indigenous peoples were explicitly mentioned in the constitution.

Even though Mexico has the largest indigenous population in the Western hemisphere ${ }^{3}$ neither the nineteenth century liberal legislation nor the postrevolutionary twentieth century laws had previously granted a specific status to the descendants of the original inhabitants. In 1992-the year of the Quincentennial Anniversary of Columbus's arrival to the New World - there were massive indigenous mobilizations all over the country, in celebration of " 500 years of anti-colonial resistance," and, in 1994, the Chiapas rebellion broke out. ${ }^{4}$ Then, in 1996, a federal government commission and the rebel Zapatista Army of National Liberation signed the San Andrés Agreements (Acuerdos de San Andrés) in the village of San Andrés Larrainzar (Chiapas). In this document, the government commission recognized the rights of indigenous peoples to their culture, communal lands, economic viability, and political autonomy. ${ }^{5}$ In 2001, after five years of demands from

2. Constitución Política de los Estados Unidos Mexicanos [C.P.], as amended, art. 4, Diario Oficial de la Federación [DO] 28 de enero de 1992 (Mex.).

3. The 2005 Conteo de Población estimates six million speakers of indigenous languages (not including children younger than five years of age). INSTITUTO NACIONAL De Estadística, Geografía E Informática, Conteo de PoBlación y Vivienda 2005. Tabulados básicos [Population and Housing Count 2005: Basic Figures] 1 (2005), http://www.inegi.org.mx/sistemas/TabuladosBasicos/Default.aspx?c=10398\&s=est (select Lengua indigena from the Tema drop down menu, and select the first item in the results) [hereinafter CONTEO DE POBLACIÓN]. But if indigenous identity is defined in a more comprehensive manner, the indigenous population can be as large as twelve million. See Comisión Nacional PaRa el Desarrollo de los Pueblos Indígenas [CDI], INDICADORES SOCIOECONOMICOS DE LOS PUEBLOS INDÍGENAS DE MÉXICO [SOCIO-ECONOMIC INDICATORS OF THE INDIGENOUS PEOPLES OF MEXICO] (2002), available at http://www.cdi.gob.mx/index.php?option=com_content\&task=view\&id=215\&Itemid=54 (citing Consejo Nacional de PoBlación [CONAPO], LA POBLACión DE MÉxiCo EN EL NUEVO SIGLO 165 (2001)).

4. On January 1, 1994, an armed group violently seized five important towns in the southeastern state of Chiapas. The majority of the rebels were Indians. These Indians presented themselves as the Zapatista Army of National Liberation (Ejército Zapatista de Liberación Nacional, EZLN) and declared war on the Mexican state. After several bloody encounters with local police forces and the national army, they withdrew to the jungle. On January 14, President Salinas ordered a unilateral ceasefire and a complicated process of negotiation began as a result. For two different perspectives on the movement, see CARLOS Tello díz, Chiapas: la Rebelión de las Cañadas [Chiapas: The Rebellion of the Cañadas] (1995); NeIl Harvey, The Chlapas Rebellion. The Struggle For Land AND DEMOCRACY (1998).

5. See Héctor díaz Polanco, la Rebelión Zapatista y la Autonomía [The ZAPATISTA REBELLION AND AUTONOMY] 229 (1997) (citing the Document 2 of the 1996 San Andres Accords, available at http://zedillo.presidencia.gob.mx/pages/chiapas/docs/ sanandres/p-conju-doc2.html). 
indigenous groups, political parties, and civil-society organizations, many aspects of the San Andrés Agreements were finally included, in a new reformation of the Mexican Constitution and also, gradually, in the local constitutions of several states. In 2004, the General Law of Linguistic Rights was passed by the Congress, and the federal government decreed the creation of the National Commission for the Development of Indigenous Peoples and the National Institute of Indigenous Languages. 6

Many critics still consider these legislative changes to be rather tepid and too generally formulated to be effective. ${ }^{7}$ In fact, even though they may be important as a first step towards a pluralistic, multicultural democracy, they have not yet transformed the conflicting nature of the relationships between the indigenous peoples and other segments of Mexican society. ${ }^{8}$ Obviously, such a transformation would require much more than legislation. But, without fetishizing the law, I contend that more pertinent and precise legislation is still needed. For instance, many exclusionary practices in Mexico result from a lack of clarity in the rules concerning indigenous political representation vis-àvis the official institutions of the Mexican government and also vis-à-vis Mexican society at large.

In this article, I shall refer to two types of exclusion, which are related to the lack of well defined forms of indigenous political representation. The first type is to be found in conflicts about the jurisdiction of indigenous authorities over communal territories, particularly in those communities that are politically subordinated to nonindigenous municipal governments. The second type manifests itself in the ambiguous status of those families that have migrated from historical indigenous villages to cities. Both types of exclusion highlight certain relevant problems for exercising the rights of citizenship among indigenous groups. In addition, I shall argue that both types are related

6. For further discussion on these constitutional and legislative changes and their political and social context, see Guillermo de la Peña, A New Mexican Nationalism? Indigenous Rights, Constitutional Reform and the Conflicting Meanings of Multiculturalism, 12 NATIONS \& NATIONALISM 279 (2006). For the official point of view on these changes, see CDI, UNA NUEva RELACIÓN: COMPROMISO CON LOS PUEBLOS INDÍGENAS [A NEW RELATIONSHIP: COMMITMENT WITH INDIGENOUS PEOPLES] (2005).

7. For a comprehensive and judicious critique on the issue, see Francisco LóPEZ BÁRCENAS, LEGISLACIÓN Y DERECHOS INDÍGENAS EN MÉXICO [LEGISLATION AND INDIGENOUS RIGHTS IN MÉXICO] 49-79 (2010).

8. See Magdalena Gómez, La Constitucionalidad Pendiente: la Hora Indígena de la Corte [The Pending Constitutionality: The Indigenous Hour of the Court], in EL ESTADO Y Los Indígenas EN TIEMPOS DEL PAN: NeOINDIGENISMO, LEgalidad E IDENTIDAD [The STATE AND THE INDIGENOUS IN THE PAN ERA: NEOINDIGENISM, LEGALTTY AND IDENTITY] 175 (Rosalba Aida Hernández et al. eds., 2004). 
to the controversy regarding what is included in the concept of culture within a nation state that now is constitutionally defined as democratic, multicultural, and pluriethnic. ${ }^{9}$

In order to exemplify such types of exclusionary practices, I shall present ethnographic information that I have collected in my fieldwork in Western Mexico between 2006 and 2009, particularly in the Sierra del Nayar-the habitat of the Wixarika (Huichol) people ${ }^{10}$-located in northern Jalisco and in the city of Guadalajara.

\section{A ROAD IN THE SACRED WIXARIKA TERRITORY}

On February 28, 2008, the ethnic authorities of the Wixarika community of Tuapurie held a press conference at a small hotel in downtown Guadalajara. ${ }^{11}$ They had traveled to the city in order to protest the construction of a paved road across the Sierra and to call for the support of the massive guard of community members that had been organized to block the road. Several representatives of NGOs, as well as some university professors and students, were among the audience.

The first speaker was the Tatewani or ethnic governor of Tuapurie, who spoke in the Wixarika language and who was translated by a university student from the same community. He ended his speech with the following words:

We the Wixaritari .. . have many ceremonial centers and sacred places.... For many generations we have

9. See Miguel alberto Bartolomé, Procesos Interculturales: ANTropología Polftica del Pluralismo Cultural En américa latina [Intercultural Processes: Political ANThropology of CUltural PluRalism in Latin AMERICA] (2006) (proposing a need to rethink political anthropology through a framework of multiculturalism and pluralism in the contemporary state, especially in regard to the indigenous population in Latin America).

10. "Huichol" is a Spanish deformation of the native term "Wixarika" (plural, "Wixaritari"). Throughout this article, I shall prefer the use of the terms "Wixarika" and "Wixaritari" to "Huichol" and "Huicholes."

11. I use the word "community" because it is the official term used to signify indigenous demarcations since the colonial period. For the Wixarika, however, a community is not a single settlement but a constellation of hamlets sharing possession of a wide communal territory. See Víctor Manuel Téllez, Tukipa: Los Recintos Ceremoniales como Fundamento del Territorio y Patrimonio Histórico-Cultural de los Huicholes [Tukipa. The Ceremonial Precincts Fundamental to the Historical and Cultural Territory and Heritage of the Huicholes], in LA antropología y el Patrimonio Cultural De México: Diversidad Y Nacionalismo [ANTHROPOLOGY AND THE CULTURAL HERITAGE OF MEXICO: DIVERSITY AND NATIONALISM] 129-88 (Guillermo de la Peña ed., 2010); see also PhIL C. WEIGAND, EnSAYos Sobre EL GraN

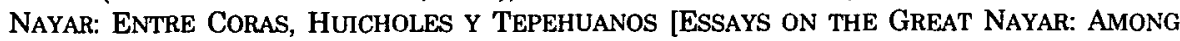
CORAS, HUICHOLES AND TEPEHUANOS] 131-53 (1992). 
taken offerings to our deities [in those places] so that our families and our world may enjoy good health .... And when we see that strange people damage our territory and sacred centers, we defend them, because [we have to protect] Tatei Yurienaka [Our Mother the Earth], and she expects this [protection] from us. ${ }^{12}$

The dispute about the convenience or inconvenience of a projected paved road had begun several years before, but open conflict had broken out in November 2007, when a communal assembly in Tuapurie was interrupted by an uninvited group of federal, state, and municipal officers, who demanded the signature of the authorities of the community for a document approving the construction of the road. ${ }^{13}$ The document was rejected by the assembly; nevertheless, the government officers announced that the road had already been approved by the neighboring Wixarika communities and that the work had already started. They also claimed that such a feat of modern communication would greatly benefit everyone. Four months later, in January 2008, the bulldozers arrived at the outer limits of Tuapurie. As a response, a large group of community members, including men, women, and children, blocked the way, and the construction had to be suspended.

The Jalisco government replied to the Tuapurie press conference by stating that the community representatives had accepted the road, without specifying which representatives. ${ }^{14}$ The blockade continued throughout the following months, with material support from Wixarika artisans and students who lived in Guadalajara and Puerto Vallarta, as well as NGOs and academics, who sent money, blankets, and food. In addition, the National Indigenous Congress-a network of local associations that had emerged in 1994 in the wake of the Zapatista rebellion-held a meeting at the very site of the blockade and broadcasted its condemnation of the road, which was defined as "a neoliberal aggression against the Wixarika people and their human rights."

12. This speech was recorded by Ubaldo Valdés Castellanos, a Wixarika student who was my assistant at the time.

13. See the reports by Agustín del Castillo, Denuncian a Sedeur por carretera huichola, PuBlico-Milenio (Guadalajara), Nov. 22, 2007, available at http://impreso.milenio.com/ node/8060711, and Juan Cosío Candelario, Imposición gubernamental sobre el pueblo wixarika, LA JORNADA (Mexico City), Feb. 24, 2008, available at http://www.jornada. unam. $\mathrm{mx} / 2008 / 02 / 24 / \mathrm{index}$.php?section=opinion\&article=012a1pol.

14. Compare the report by Agustín del Castillo, Profepa no investiga denuncia huichola, PUEBLO INDIGENA (July 13, 2010), http://www.puebloindigena.com/portal/ noticias_374.html. 
One of the press releases from the Tuapurie authorities also condemned the imposition of "a neoliberal vision of so-called progress." In addition, they accused the Mexican government of bad faith:

We don't want that which they call progress ..... We know that behind [all this] is the ambition of the government ... in alliance with transnational capital. They want to impose tourist megaprojects on our places of worship ... [and to open the way to] the spurious ecological tourism which attempts to commercialize our culture ... . [They plan to] create hunting areas in our communal reserves, to give concessions to mining and timber enterprises, to plunder our natural resources ... . [and] to steal the land which our ancestors cherished and looked after ... the land which is legally recognized as our land by the Mexican government. ${ }^{15}$

Such a radical discourse implied a collective representation of the past of the community as a history of grievances and plundering, as well as a vision of the communal territory, not as a resource to be economically exploited, but as a precious inheritance infused with religious meanings. But the discourse was also a manifestation of the ambiguity of the legal and political situation of many indigenous communities. In administrative and political terms, Tuapurie depends on the municipality of Mezquitic, which has always been ruled by a nonindigenous mayor and a nonindigenous municipal council. Even though the constitution now declares the indigenous communities to be politically autonomous, the local congresses are left to determine how autonomy is to be defined and exerted. In the State of Jalisco, the local congress ruled that indigenous communities may elect their authorities according to their own traditions; their competence, however, is limited to internal order maintenance and arbitration. ${ }^{16}$ Thus, for matters which implicate external relations, the indigenous authorities have to depend on the municipal government. The amended Article 4 of the Constitution of Jalisco also established that the indigenous representative institutions should be consulted in matters that could affect communal interests, but it is not clear how "representative

15. See note 12; see also Press Release, Tuapurie Community, La Comunidad de Tuapurie-Santa Catarina Cuexcomatitlán, Piden Detener Construcción de Carretera [The Tuapurie-Santa Catarina Cuexcomatitlán Community Demands the Suspension of Road Building] (Feb. 28, 2008) (available at http://cencos.org/node/17962).

16. See Constitución Política del Estado de Jalisco, as amended, art. 4.A, Periódico Oficial El Estado de Jalisco, 5 de Febrero de 2007 (Mex.). 
institutions" are defined. ${ }^{17}$ This is particularly complicated in the case of the Wixaritari, because each community has several bodies of authority, namely the council of elders, the (colonially originated) communal government, the shamans or religious leaders, the agrarian committee, and the assembly. The assembly is convoked by the agrarian committee and is regarded by the Wixaritari as the supreme organ of deliberation and rule; but, under Mexican law, it is only an instrument of agrarian administration. Thus, if the Wixaritari argue that the road cannot be built because the assembly has not approved it, municipal, state, and federal authorities may answer that the opinion of the assembly is not the decisive factor.

In the last analysis, the challenge exemplified by the road dispute in the Sierra del Nayar is how to construct legal and political processes allowing members of indigenous communities fully to exercise their rights of citizenship. ${ }^{18}$ Without such instruments, communities will effectively continue to be excluded from strategic decisions concerning the uses of their territory.

\section{URBAN INDIANS: IN THE CITY WITHOUT CITIZENSHIP}

The second type of exclusion on which I focus in this article is related to the increasing overflow of the indigenous communities toward urban areas.

In many instances, the expanding Mexican urban areas have devoured the old indigenous communities situated on their fringes. It is not exceptional that these enclosed communities maintain their historical institutions, but the constitutional reforms of 1991 and 2001 did not make any provisions for their protection or recognition. In any case, the majority of the indigenous persons who live in cities at present are there as the result of a massive migration from the rural areas, which started around 1970. In this connection, it is pertinent to point out that in the metropolitan areas of Mexico City, Guadalajara, and Monterrey, as well as in the cities of the northern international border and in the towns of the Caribbean "Mayan Riviera" (Cancún and Playa

17. Id.

18. When I revised this article in the summer of 2010 , the dispute had not been resolved. See Tunuary \& Christian Chávez, Pueblo wixárica. Derecho hasta sus últimas consecuencias [Wixárica People. Right Through to the End], LA JORNADA JALISCO (Guadalajara), Dec. 3, 2009, available at http:/www.lajornadajalisco.com.mx/2009/12/03/ index.php?section=politica\&article $=008 \mathrm{a} 1 \mathrm{pol}$. 
del Carmen), the indigenous population grows faster than in any other part of the country. ${ }^{19}$

In Guadalajara, the 2000 National Census registered speakers of more than thirty indigenous languages, of whom the most numerous are speakers of Wixarika, Purépecha, Otomí, Náhuatl, and Mixtec, but the Zapotec, Mazahua, Triqui, Tlapanec, Zoque, Tseltal, and Tzotzil are growing in importance. ${ }^{20}$ In the early $1970 \mathrm{~s}$, migrants were mostly males who worked for a while in the city and then went back to their villages. But, since the mid-seventies, the Mexican rural economy has suffered one disaster after another; in consequence, not only males but entire families have moved to cities. ${ }^{21}$ Many of them live in so-called "irregular" settlements without legal registration or urban services and have precariously survived, working in the informal sector of the economy.

A great many indigenous migrant families have lived in Guadalajara for two or three generations. ${ }^{22}$ From the point of view of the urban municipal governments, and urban society in general, the

19. See Miguel Ángel Rubio et al., Desarrollo, marginalidad y migración [Development, Marginalism and Migration], in 1 ESTADo DEL. DESARROLLo ECONÓMICO Y SOCIAL DE LOS Pueblos Indígenas De México [STAte of Economic and Social Development of the INDIGENOUS PEOPLE OF MEXICO] 289 (2000); see also ENTRE LUCES Y SOMBRAS: MIRADAS Sobre los Indígenas En El Área Metropolitana De MonTERREY [BETweEn Lights AND SHADOWS: ViEWS ON THE INDIGENOUS IN THE METROPOLITAN AREA OF MONTERREY] (Séverine Durin ed., 2008).

20. See Conteo De Población, supra note 3, at 10 (click the second link in the search results); see also GUILLERMo DE LA PEÑA, CULTURAS INDIGENAS DE JALISCo [INDIGENOUS CULTURES OF JALISCO] (2006) (explaining how indigenous people from the state of Jalisco have converged on Guadalajara, and as a result, have become part of the city, while transforming it as well).

21. See Eugenla Bayona Escat, la Ciudad Como Oportunidad y Como Peligro: La CoMunidad Migrante de Comerciantes PuRÉpechas EN Guadalajara [THE CITY aS OPPORTUNity AND DANGER: THE MIGRANT COMMUNITY OF PURÉPECHas DEALERS IN GUADALAJARA] (2007); REGINA MARTINEZ CASAS, VIVIR INVISIBLES: LA RESIGNIFICACION Cultural EnTre los Otomies Urbanos de Guadalajara [LIVING INvisibles: The Cultural REsignification AMONG the URban OtOMI OF Guadalajara] (2007);

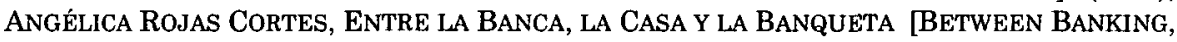
THE HOME AND THE BANQUET] (2006).

22. It is difficult to give an exact figure for indigenous people in Guadalajara. As in the rest of Mexico, perception of phenotype is not a crucial criterion for defining who is or is not indigenous; factors of culture and language, as well as self-identification and reference groups, are much more important. According to the official 2005 Conteo de Población, only 20,256 people older than five years of age living in the metropolitan area of Guadalajara (which at the time had over four million people in six municipalities) spoke Amerindian languages. According to the National Commission for the Development of Indigenous Peoples, the real figure is probably five times larger, among other reasons because respondents frequently hide their language and their origins for fear of discrimination. CDI, supra note 3 . 
identity of these families is rather difficult to define. Supposedly, indigenous persons do not belong in cities, and, if they do, it is because they have changed their customs and become "like everybody else." What has happened, however, is very different. Most families have kept close linkages with their communities; many of them speak their native languages at home and try to maintain strict control over the habits of younger generations. Ethnic endogamy is considered an obligation, as well as visits to the village of origin for the festivities of the saints, which function as ethnic symbols and tools for cultural reproduction. To wear traditional indigenous dress in the city is useful for certain occupations, such as the selling of handicrafts and food or the performance of music and dance for tourists. It is not exceptional that households and kinship groups retain corporate functions of production and consumption similar to the functions they had in the rural areas. For instance, Purépecha extended families live and work together; men, women, and children participate in the manufacturing and selling of furniture and clothing. The Otomí households manufacture and sell rag dolls and potato chips. But even when families and kindred do not work together, they still manage to meet frequently. Náhuatl-speaking young women from the Huasteca Sierra find jobs as domestic servants (often living at the house of their employers), while Náhuatl-speaking young males from the same region are masons, gardeners, and kitchen assistants in restaurants. On Sundays, all of them get together in a public park. They also organize balls. Couples rent rooms to spend the weekend together. And, for the Christmas and All Souls festivities, they charter buses and visit their villages. The Mixtec have a wide range of activities as musicians, street vendors, masons, and raffia weavers-but they work with their kin, retain membership in religious sodalities in their communities, and have promoted organizations of neighbors in the city. Wixaritari are an exception to this type of migrant life centered on the family, because most of them are students whose families remain in the Sierra. However, they do rent houses or apartments in groups. On the weekends these groups meet in a sports field, and they visit their communities for major festivities and to provide help during peak periods of agricultural work. ${ }^{23}$

23. See luis francisco Talanera, Los Pueblos de lluvia y de la Madera.

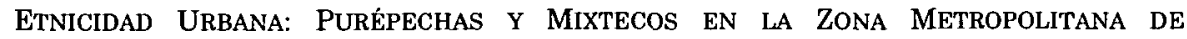

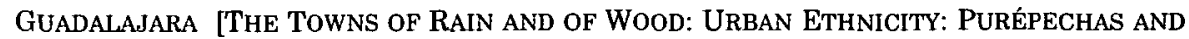
MiXtecos in the Metropolitan Zone of Guadalajara] (2006); Cristina Alfaro, ¿SU CASA Es Mi CASA? [Your Home is MY Home?] (2007); Guillermo de la Peña, ¿Una Nueva Categoria Analítica? Los Indigenas Urbanos en la Antropología Mexicana [A New Analytical Category? The Urban Indigenous in Mexican Anthropology], in LA ANTROPOLOGÍA Y LA CONSCIENCIA NACIONAL MEXICANA [ANTHROPOLOGY AND THE MEXICAN NATIONAL CONSCIENCE] 213 (Claudio Esteva-Fabregat ed., 2010); Regina 
The above does not mean that migrants simply "transplant" their ethnic cultures to the city. What we find are processes of ethnogenesis, by which indigenous migrants recover and resignify ideologies, symbols, discourses, and practices from their communities of origin and construct new identities and cultural forms in the urban setting. These processes of ethnogenesis are vehicles for survival and self-esteem in a context of inequality and racism. In the city, it is frequent to hear dismissive, patronizing, or even hostile expressions about los indios, the Indians, among all social classes. At schools, children who are classified as Indians are mocked or even insulted by other children. Some teachers scold them because of their accent and their grammar and accuse their parents of child exploitation because of the custom of family joint work. Employers regard indigenous laborers suspiciously and pay them lower salaries, and fellow workers make fun of their speech and manners. Such hostility could potentially cause some parents to encourage their offspring to speak only Spanish and try to forget their origin, so that children do not suffer negative discrimination as much as they did. But hostility also provokes feelings of hatred and resentment against nonindigenous society, feelings that are intensified by the lack of formal institutions through which they could channel their complaints and demands as indigenous members of an urban collectivity.

Similar to the first type of exclusion mentioned in this paper, this second type of exclusion is also about unfulfilled citizenship. In the constitution, indigenous communities are always defined in relation to settlements located in a historically distinctive territory. Within this definition, indigenous migrants who live in cities have no place. If rural indigenous communities suffer from ambiguity in their capacity of representation before municipal, state, and federal authorities and Mexican society in general, urban indigenous groupings suffer from something more radical: a total absence of legal and political recognition.

\section{ON CULTURE AND INTERCULTURAL DIALOGUE}

I shall now refer to the relationship between indigenous exclusion and certain usages of the term "culture." Communal authorities, ethnic intellectuals, as well as leaders of urban indigenous organizations and

Martínez Casas \& Guillermo de la Peña, Migrantes y comunidades morales: resignificación, etnicidad y redes sociales en Guadalajara [Migrants and Moral Communities: Resignification, Ethnicity and Networks in Guadalajara], 13 REVISTA DE ANTROPOLOGÍA SOCIAL 211 (2004) (explaining the classical concept of community by comparing the Alteño and Otomi migrants in Guadalajara) (Spain). 
NGOs, frequently discuss the necessity of defending "the culture." 24 They complain about the loss of languages, customs, and wisdom inherited from the ancestors, as well as the scorn that young people show toward their history and identity. Often the blame is put on schools, contacts with nonindigenous groups, and migration. Interestingly enough, their discourses usually imply an organicist concept of culture: culture as a harmonious totality of values, symbols, and practices; culture as the natural expression of "a people," which is in turn conceived as a coherent, timeless unit. Supposedly, this essentialized idea of culture is inspired by anthropological theories, even though certainly in the last forty years anthropologists have referred to culture as a contradictory process mediated by asymmetrical power relationships and therefore situated in a context of dissidence and change, conflict, and negotiation. ${ }^{25}$

In fact, conflicts and negotiations are evident in the past and the present of indigenous peoples in Mexico. At present, dissidence and mutation are part and parcel of their everyday life. For instance, if the majority of the members in the Wixarika community of Tuapurie are vehemently opposed to the opening of the road, many of their neighbors in the Wixarika community of Tateikie welcome it, and they have already started a project of ecological tourism, which the people of Tuapurie find outrageous. An obvious dissidence is also found among the young people of different communities in the Sierra del Nayar, who are not very keen on participating in communal rituals and would rather prefer to go to parties in neighboring mestizo towns. In the Sierra, the most serious dissidence is based in religion: those families converted to evangelical denominations become the object of communal

24. For a powerful exaltation of indigenous cultures in contemporary Mexico written by a prestigious anthropologist, see GUILLERMO BONFIL BATALLA, MÉXICo PROFUNDO: UNA CIVILIZACión NEGADA [DEeP MEXICO: A DENIEd CIVILIZATION] (1989). For a presentation of the "anthropological" method that NGOs and ethnic leaders can use for the strengthening of indigenous "communal cultures," see also JUAN JOSÉ RENDÓN, TALLER DE DiÁlogo Cultural [Workshop of Cultural Dlalogue] (2004). Most documents and statements of the National Indigenous Congress are written in the same vein. See, e.g., Archivo de Documentos sobre derechos y cultura indigena, CENTRO DE ESTUDIOS ANTRopológicos, Científicos, ARTísticos, Tradicionales Y Lingüísticos, http://ceacatl.laneta.apc.org/ (click "Archivo" on the left-hand menu).

25. For reviews of recent anthropological thought, see BRUCE KNAUFT, GENEALOGIES of THE PRESENT IN CULTURAL ANTHROPOLOGY (1996), and for reviews specifically on Mexican anthropology, see LA ANTropología Sociocultural EN EL MÉxico DeL MILENIO: BÚSQUEDAS, ENCUENTROS Y TRANSICIONES [SOCIOCULTURAL ANTHROPOLOGY IN MeXico AT THE END OF THE MiLlenNiuM: SEARCHES, EnCOUNTERS, AND TRANSITIONS] (Guillermo de la Peña \& Luis vázquez León eds., 2002). 
hostility and some of them have been evicted from their localities. ${ }^{26}$ In the cities, many young women rebel against household duties and search for better school and employment opportunities. A number of them also show reluctance to dress like their mothers and aunts or to have their husbands chosen by their parents.

Indigenous intellectuals and leaders often react to all of these facts by calling for a movement in defense of cultural integrity as defined by the authority of elders. While this "strategic essentialization" can be a valuable asset to rally communal support in situations of confrontation, it is sometimes counterproductive. ${ }^{27}$ Paradoxically, among certain sectors of the nonindigenous dominant society, cultural integrity is also seen as a characteristic of indigenous communities but with a negative connotation. It is said, for instance, that "Indians" cannot become "modern" because of their cultural imperatives and taboos. Further, images of "the native world" as idyllic and exotic, which are spread by tourist businesses and also by government cultural bureaucracies (and even by school textbooks), strengthen the same idea. ${ }^{28}$ Unfortunately, the conception of culture as something immutable and untouchable reinforces the difficulty of intercultural dialogue and therefore aggravates the problems of recognition and representation.

Intercultural dialogue and intercultural recognition should imply that cultural diversity is valued without making a fetish out of culture. In the case I presented of the conflict over the road in the Sierra Huichola, there were two opposed conceptions of the territory-as a resource to be exploited or as an inheritance to be respected and cherished-and also two opposed visions of development and governance-a hegemonic vision emphasizing the primacy of national integration through transport facilities, the market, and modern technology, and a subaltern conception, claiming communal autonomy within the nation state, which would imply respect for a development strategy compatible with ancestral cosmology. These two opposite conceptions answer to different cultural priorities. Yet the actual translation of these priorities into discourses and practices is always mediated by social relationships among individuals and groups with specific class interests and differential power. An adequate political

26. Guillermo de la Peña, Social Citizenship, Ethnic-Minority Demands, Human Rights, and Neo-Liberal Paradoxes: $A$ Case Study in Western Mexico, in Multiculturalism IN LATIN AMERICA: INDIGENOUS RIGHTS, DIVERSITY AND DEMOCRACY 129, 133-44 (Rachel Sieder ed., 2002).

27. $C f$. Gayatri Chakravorty SpIvak, In Other Worlds: Essays IN Cultural PoLITICS (1998).

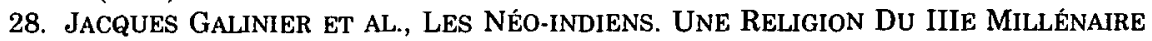
(2006). 
representation would allow for public discussion on the legitimacy of diverse interests, both communal and governmental. Similarly, proper political representation for indigenous persons who live in cities would allow for the public defense of their citizen rights, which, according to the constitution, now include the open display of their ethnicity and cultural practices.

I argue that defending the right to publicly display cultural differences does not mean that one is defending the existence of ethnic cultures as immutable cultural spheres, totally independent from national culture. It would be equally misleading to proclaim the existence of separate, static systems of indigenous law. There are many instances in which the Wixarika use the language of human rights, and not only the language of custom, as an effective tool in their internal disputes. They have appropriated the discourses of human rights, in the same way as they appropriated the discourses against neoliberalism and transnational tourist business. Similarly, they often invoke national agrarian law, and not only ancestral legacies, in the defense of their communal land. These examples of "situational selection"-choosing the norms that are more advantageous for a given situation-are not mere opportunistic strategies; they exemplify possibilities of dialogue and negotiation across differences. Hopefully, the extension of legislation will allow for the continuity of such dialogue. For instance, an obvious move would be to recognize the Wixarika communal assembly as a body with functions of decision making and political representation in matters related to rights that are already constitutionally recognized, such as the right of the community to be consulted when the uses of its resources are concerned..$^{29}$ With respect to the urban indigenous groups, it would be important to institute authoritative bodies with the functions of channeling their demands and monitoring the respect accorded to their rights in the city. ${ }^{30}$ Changes related to specific forms of ethnic representation before the local and the national legislatures would be more controversial since they involve constitutional amendments, but such amendments are necessary antidotes to legal indigenous exclusion. It goes without saying that all of these changes pose crucial and unavoidable challenges for the future of Mexican plural citizenship and democracy.

29. The State of San Luis Potosi has already modified its constitution to recognize different types of local traditional authorities within its jurisdiction. See Constitución Política del Estado Libre y Soberano de San Luis Potosí, as amended, art. 9, Periódico Oficial del Estado Libre y Soberano de San Luis Potosí, 5 de febrero de 2009 (Mex.).

30. For instance, this would include the rights to bilingual education, the maintenance of custom, and the public use of ethnic symbols. 
